\title{
Using Technology to Promote Academic Success for Students with Learning Disabilities
}

\author{
Ali M. Alghazo, PhD \\ Department of Human Resource Development, Master's Program \\ Prince Mohammad Bin Fahad University \\ Boshra E. Al-Otaibi \\ Department of Human Resource Development, Master's Program \\ Prince Mohammad Bin Fahd University
}

Received: May 22, 2016 Accepted: June 6, 2016 Published: August 1, 2016

doi:10.5296/jse.v6i3.9638 URL: http://dx.doi.org/10.5296/jse.v6i3.9638

\begin{abstract}
The following research paper provides intends to act as an authoritative reference point for information related to using technology to promote academic success of students with Learning Disabilities (LD) based on information retrieved from various sources. The major objectives of this study are: To explore the advantages resulting from usage of technology to promote academic success for students with learning disabilities; To understand the obstacles that hinder the successful implementation and integration of technology that could be used to promote academic success for students with learning disabilities. To answer the question of how can technologies be used and integrated in the best possible manner to promote academic success for students with learning disabilities? The methodology used in the following study is a systematic literature review of relevant research studies and articles. A methodical analysis of previous literature is an imperative part of any academic research project (Webster \& Watson, 2002). A comprehensive, high-level literature review forms the basis and motivation for constructive and extensive research (Boote and Beile, 2005, p. 3). The study found that schools and educationists need to execute requisite pedagogy in such a manner that students with LD are benefitted rather than confining them to special instructions and objectives. Integrating technology into regular education to support students with LD need not be costly or necessitate massive training. Assistive technology ranging from low-tech devices like pencil grips to advanced software like speech recognition software can empower children having LD with the skills required to take forward their education in an
\end{abstract}




\section{Macrothink}

Journal of Studies in Education

ISSN 2162-6952

equivalent manner like their peers. Emerging technologies like social networking sites and freely available communication software can aid effective association with teachers and peers. Continuous policy up gradation and research can immensely contribute towards technology incorporation within teaching lessons for students with different academic LD.

Keywords: Technology Education, Learning Disabilities, Academic Success, Academic Performance 


\section{Introduction}

The capability of assistive technology in education classes for students with learning disabilities (LD) is enormous. Some of the advantages of using technology include promoting academic success for students with LD in the field of writing, mathematics, spelling, reading and comprehension, enhancing their organizing capability and most importantly encouraging their social inclusion in society (Quenneville, 2015). Support or assistive technology offers many advantages by assisting writing for students with LD who usually find writing to be cumbersome (MacArthur, 1996). Once students overcome writing issues, they tend to be more successful within the general education environment. Also such children find it challenging to retain information from the standard syllabus. Many teachers face difficulty adapting curriculum as per the learning requirements of children with LD without any external assistance. Hence, it has become all the more important to focus on this issue to help teachers incorporate technology within the classroom to promote learning of children with LD (Wilson et al., 2011). The Office of Special Education Programs (2011) recommends the usage of commonly available technology for children with LD to be included within the classroom (US Department of Education, 2014). This research paper focuses on the crucial topic of how best technology can be used to promote academic success for children with LD.

The No Child Left Behind Act of 2001 (NCLB, 2002) has acted as a catalyst in improving school facilities to meet the needs of the children with disabilities. Even though most of the schools have responded positively to implement the required changes, some of the educational institutes do not have the right direction regarding the correct measures to be taken. They are confused regarding the key elements that can result in effective organized change and the manner in which the teachers can be supported to assist learning of students with disabilities (Reed, Clifford \& Svedkauskaite, 2004). Most of them have implemented assistive technologies for students with disabilities to create a well-defined approach towards change that can benefit all categories of students, even that group of children acknowledged by the NCLB Act. Use of assistive technology to aid learning of children with disability is, thus, gaining prominence with the widespread usage and easy availability of technology. Hence, looking to the importance of this subject, it will act as an informative source for educational providers to guide them further in their endeavor to aid learning of children with disabilities.

\section{Literature Review}

Children with learning disabilities have neurologically-based managing issues that change the manner in which they receive, process or communicate information. These managing or processing issues can impede the learning of basic essential skills like writing, math and/or reading. Higher level skills like time planning and management, short or long term memory and concentration, organization and conceptual reasoning may also be affected. Learning disabilities affect not only the academics part of life but can also affect social aspects such as relations with friends, family and colleagues. Learning disabilities and learning problems should not be mixed. Learning problems are basically due to impairment of the hearing, motor or visual skills. Learning problems can also be due to emotional issues, mental 
retardation or cultural, economic or environmental problems. On the other hand, children with learning disabilities have an average or above average intellect. However, a gap exists between the person's capability and actual accomplishments; hence they are also known as hidden disabilities. There is no permanent cure for learning disability. However, if students with learning disabilities are provided with suitable assistance and intervention like proper usage of technology they can attain success in academics, relations, office and society (LDA, 2015; NIH, 2014; American Academy of Child \& Adolescent Psychiatry, 2015).

The academic success of students with learning disabilities can be promoted with the help of assistive technologies. As per the definition proposed under Sec. 602 (1) of the Individuals with Disabilities Education Act Amendments (IDEA) (1997, p.8), an assistive technology is any kind of tool or product practice either bought commercially, altered or custom-made that is utilized to augment, uphold or enhance the functional abilities of people with disabilities. Functional capability can be any activity that the student is expected to do like moving within the school premises, interacting, hearing, seeing, writing, reading and similar other tasks. Almost 6.5 million students with disabilities have benefitted from assistive technologies implemented under the Individuals with Disabilities Education Act (IDEA) of 1997. Assistive technology fulfills two main objectives. First is augmentation of strengths of an individual, thus helping to overcome the impact of disability and second is to present a substitute method for executing an activity (Lewis, 1998). Thus, the usage of technology enables students to counterbalance their disability or overcome it completely.

Assistive technology can help students with LD to replace an ability that is either absent or weakened. It offers the support required to complete a task successfully. There are various computer technologies that can be used to help students with diverse LDs like software that can help in writing, math skill improvement and reading, OCR (optical character recognition) or scanning, e-books, text-to-speech, providing options of bigger print, color and highlighting, abbreviation expansion and predicting words, grammar and spelling checkers, speech input, mathematics and writing tools and idea managers.. For instance, word processing helps students with LD in enhancing their writing skills. Computers can act as motivating factors for disinclined writers to write by assisting their motor activities, offer help with spelling, editing and revision and generates a neat and readable document. Students who have fine motor issues are not commonly selected to play the role of recorder during combined learning sessions. If such students can use portable note takers, they can successfully record group answers. Students having spelling issues can use tools for checking spellings or look for definitions during a combined writing assignment. MacArthur \& Graham (1987) found no variations in the number or kind of revisions made by students using either word processor or with the help of paper and pencil. However, a study by Vacc (1987) discovered that students with LD invest more time in writing and revision when using computers as compared to writing by hand. Further investigation by MacArthur, Graham and Schwartz (1991) found that when usage of computers is facilitated with clear and effective instructions regarding revision, word processing results in higher advantages for students having writing LD. Computer-based graphic organizer is one of the most powerful learning and evaluation tools for recognizing gaps within the knowledge base of a student. Its electronic version provides a 
convenient way to refine concept maps and assists the distinctive learning approaches and requirements of students with LD (Anderson-Inman, Ditson \& Distson, 1998). Some of the advanced graphic organizers also allow creation and depiction of information in various forms, provide various methods to complete an assigned task and permit students to change the formats (Tenny, 1992). Thus, technology can contribute greatly towards academic success of students with learning disabilities.

Technology plays a significant role in promoting inclusive classrooms. Employing technology promotes a feeling of belonging and encourages interactive involvement in regular education classes for students with LD (Bryant \& Bryant, 1998). Technology assists in increasing the regularity of successful completion of assignments and plays an important role in improving motivation of such students (Bahr, Nelson \& VanMeter, 1996). It, thus, helps in achieving the fundamental aims of inclusive education like inculcating a feeling of belonging to the group, sharing activities with exclusive results and giving an experience of a balanced education.

Many educators and administrators, irrespective of their prior experience, are supposed to be agents of change in improving school facilities and be well informed and acquainted regarding assistive technologies, in spite of the field of assistive technology being so wide and being comparatively new (Wilson et al., 2011). Even though many schools have facilities for technology assisted teaching, it is not being used effectively either due to incapability of the class teacher to include the technology within the class module or due to lack of sufficient time as incorporating learning technology into class session requires proper planning. The implementation and usage of technology should be a collaborative attempt. Collaboration has many dimensions within an educational environment. Cook and Friend (1996) have described aspects of successful collaboration. One of the most important aspects for making technology a part of the regular education class are mutual responsibility of participating and decisiveness, acquiring and sharing technical resources and sharing responsibility for the results of students. Inclusion of technology requires effective collaboration of class teachers with assistive technologists. The technology requirements of a student are evaluated by assistive technology specialists in association with class teachers, relevant services personnel, students and parents. The specialist considers the motivation level of user and the user's feedback regarding specific adaptations. For instance, the idea of using a portable note-recorder may not be comfortable to a particular student. The assessment process is facilitated by the staff members who help in recognizing and listing the strengths and weakness of students during regular education classes. The team, in a combined manner, discusses and decides a suitable device, requirements for particular setting and the features of the student, which can be improved. Once a suitable technology is decided, assistive technology specialists train and consult teachers, parents, associated services staff and students. Ultimately, it will be the responsibility of students and class teachers to integrate technology within the regular class schedules.

Thus, based on literature review, it can be rightly concluded that using the right technology is one of the most effectual methods to assist meaningful education and develop important thinking skills of students with learning disabilities. It can assist students with LD to 
overcome difficulties in learning, particularly in the fields of writing with the help of computer assisted tools. Also, technology helps to alleviate frustration, encourage a feeling of being socially accepted by peers, improves motivation level and enhances productivity level of students within and outside the class. Revision in IDEA recommends that assistive technology should be a part of IEPs (individualized educational plans). For this, a vision and understanding of required technology for students on an individual basis needs to be developed by collaborative planning teams. The effectiveness of available technology and the student's capability should be closely monitored to make the required changes as per the varying capabilities of the student. Effectual teacher training and providing the right guidance to encourage effective and regular use of varied technologies in the curriculum should be done to successfully integrate technology within regular education systems. The complete strength of assistive technology for students with LD is yet to be explored and holds much potential for the future. Technology could be the answer for students with LD to overcome hurdles in their academic success.

\section{Methodology}

\subsection{Research Questions and Objectives}

Based on the literature review, the major objectives of this study are:

1. To explore the advantages resulting from usage of technology to promote academic success for students with learning disabilities.

2. To understand the obstacles that hinder the successful implementation and integration of technology that could be used to promote academic success for students with learning disabilities.

Thus, this research will include discussions related to the advantages of using technology to promote academic success for students with learning disabilities and the obstacles faced during the implementation and integration of technology within the educational system to address the following research question:

How can technology be used and integrated in the best possible manner to promote academic success for students with learning disabilities?

\subsection{Methods}

To accomplish the above mentioned research objectives, a systematic literature review of relevant research studies and articles will be conducted. A methodical analysis of previous literature is an imperative part of any academic research project (Webster \& Watson, 2002). A comprehensive, high-level literature review forms the basis and motivation for constructive and extensive research (Boote and Beile, 2005, p. 3). Such quality analysis of existing research studies have many benefits like helping to demarcate what research has been conducted and what is required to be conducted in future, ascertain variables relevant to the subject, ascertain relation of concepts with actual practice, avert unintended and redundant duplication, identification of major research techniques and designs that have been used, ascertain inconsistencies and discrepancies and identification of strengths and drawbacks of 
different research methods that have been used (Onwuegbuzie, Leech \& Collins, 2010).

The first step in the literature review involves conducting a search of suitable databases to identify peer reviewed literature worthy of inclusion.

\subsection{Search Strategy}

One of the most commonly used techniques to find relevant literature is by conducting keyword searches (Ely and Scott, 2007). The keywords used to carry out the literature search were: "using technology to promote academic success of students with learning disabilities," "advantages of using technology to educate students with learning disabilities" and "obstacles in implementing technology to educate students with learning disabilities". Thesaurus terminologies and difference in British and American spellings were also considered to widen the search. Boolean operators like AND and OR were used to ensure wider coverage of literature as part of the search strategy.

\subsection{Inclusion and Exclusion Criteria}

In order to methodically narrow down the search and to make the assessment process more convenient, inclusion and exclusion criteria was developed. The following inclusion and exclusion criteria were used to include relevant articles:

Table 1. Inclusion \& Exclusion Criteria

\begin{tabular}{|l|l|}
\hline Inclusion Criteria & Exclusion Criteria \\
\hline $\begin{array}{l}\text { Clear abstract explaining the } \\
\text { objective concisely }\end{array}$ & $\begin{array}{l}\text { Research studies not meeting the } \\
\text { inclusion criteria }\end{array}$ \\
\hline Qualitative Research & $\begin{array}{l}\text { Editorials, views, guiding principles } \\
\text { and studies not presenting empirical } \\
\text { evidence }\end{array}$ \\
\hline $\begin{array}{l}\text { Use of interviews } \\
\text { analysis }\end{array}$ & $\begin{array}{l}\text { Method inappropriate, or not } \\
\text { clearly explained }\end{array}$ \\
\hline $\begin{array}{l}\text { Conclusions are supported by the } \\
\text { results with empirical proof }\end{array}$ & $\begin{array}{l}\text { Rechnology to promote academic } \\
\text { success of regular students or } \\
\text { students with other health issues }\end{array}$ \\
\hline $\begin{array}{l}\text { Having reference to students with } \\
\text { learning disabilities }\end{array}$ & $\begin{array}{l}\text { research analysis } \\
\text { Location: Anywhere across the globe }\end{array}$ \\
\hline
\end{tabular}




\subsection{Critical Appraisal Skills Programme (CASP)}

The framework used to critique the articles will be the Critical Appraisal Skills Programme (CASP) framework (CASP, 2013). CASP has been chosen as it has separate frameworks for quantitative and qualitative research; this literature review concentrates on qualitative literature, as the subject matter relates to how technology can be used in the best possible manner to promote academic success of students with learning disabilities, which is descriptive rather than numerical. The CASP framework uses a series of ten questions to systematically evaluate whether the results of the research are valid, what those results are, and how they might influence personal practice (Lee, 2006).

The initial two questions of CASP framework determine whether it is in fact worth continuing with the research paper at all. It is important that the papers to be included contain a clear and concise statement explaining the aims (Polit \& Beck, 2010). The next question focuses on whether or not qualitative research is an appropriate method for the research question. Some research questions are best addressed through qualitative analysis and others by quantitative analysis (Pooler, 2012). This project is clearly seeking to use a qualitative paradigm, as the data collected will be qualitative (Moule \& Goodman, 2014). Qualitative research allows the researcher to study things in their natural environment in an attempt to interpret or make sense of observed phenomena (Denzin \& Lincoln, 2000).

The next question assesses the appropriateness of research design. The answers were then thematically analysed as described by Braun and Clark (2006). As with any thematic analysis, the themes will be influenced by the authors, which may constitute a form of bias (Joffe \& Yardley, 2004). The next point considers whether the recruitment strategy is appropriate. The way in which the data is collected should be clearly explained, and where the research is qualitative the researchers should give some consideration to the potential impact of any relationship between the researcher and participants. Ethical approval should be sort, and granted, and the details of how the research was explained to participants are quite clear, and ideally there should be consideration given to how participation in the study might affect the respondents (Carpenter, 2011).

The final questions in the CASP framework consider the results, including the data analysis, the findings and the wider applicability. The research papers included are all likely to be of value to those working with students having learning disabilities.

\section{Discussion and Results}

Students with LD have always felt sidelined as usually they are given different class settings as compared to most of the peers of their age (Berry, 2006; McPhail \& Freeman, 2005). Due to their isolation they gradually continue to remain below par as compared to their peers in regular classes (Van Kraayenoord, Miller, Moni \& Jobling, 2009). Research has clearly shown that students with LD learn better in an inclusive environment, where they can constructively engage with their peers and are involved in genuine educational learning actions (Graham \& Perrin, 2007). Technology can play an important role in creating inclusive environment for students with LD. The AT Act specifies that all students should be able to 
access technology that helps in the execution of life activities like learning, recreation, work and leisure. Assistive technology can help such students define their objectives, make design choices and evaluate their own progress. It also allows students to actively think regarding information, make informed choices and exhibit their talent as compared to the conventional teacher focused lessons (US Department of Education, 2010). This chapter will highlight how usage of assistive technology can improve learning for children with LD and how it can contribute to their academic success by utilizing their strengths to compensate for their disabilities. This section intends to be a good referencing source for educationists and parents about the role of assistive technology in assisting their children with LD and prepare them for success in academics and for future challenges.

\subsection{Using Technology to Improve Reading Skills}

Improvement in reading skills gains more prominence as students are presented with new and complex reading materials in higher classes. The reading ability of a student is one of the key determinants of their educational success (Pitcher, Martinez, Dicembre, Fewster \& McCormick, 2010). As per a study by Fletcher, Stuebing, Barth, Denton, Cirino, Francis \& Vaughn (2011), a student's cognitive strengths and limitations can be evaluated based on their reading fluency and reading knowledge. A study by Calhoon, Sandow and Hunter (2010, p.57) found that having customized interventions as per the students requirements increases the reading ability of students with LD as compared to having interventions in general for the entire class. Reading interventions like technology help to recognize, describe and work out the literacy problems of students with LD with the help of multi-level and research based instructional techniques (Fuchs \& Fuchs, 2006; Shores \& Bender, 2007; Haager, Vaughn \& Klingner, 2007).

Technology can help in improving reading fluency with the help of an explicit version, give students various chances to repetitively read known text without help along with providing feedback for correction and establishes performance standards as the text difficulty increases (Chard, Vaughn \& Tyler, 2002). One of the techniques to accelerate the inadequate reading skills of students with LD is READ 180 program, a complete reading intervention method, recommended to be used in elementary, middle and secondary schools of US ( Hartry, Fitzgerald \& Porter, 2008; Hewes, Palmer, Haslam \& Mielke, 2006, Slavin, Cheung, Groff \& Lake, 2008; White, Haslam \& Hewes, 2006; Scholastic Inc., 2011). This program helps students with LD to learn techniques related to decoding and paraphrasing, thereby improving their academic performance (Schumaker, Deshler, Woodruff, Hock, Bulgren, \& Lenz, 2006). READ 180 makes use of different types of technology across all facets and phases of its program enabling teachers to evaluate and modify as per the students' requirements with the help of technology.

Apart from READ 180, computer-aided instructions and Internet-connected tools that support interpretation of text for the student have been found to have a positive effect on the reading command of students with LD (Stetter \& Hughes, 2010). Thus, reading intervention techniques using technology helps students in receiving the most excellent reading lessons useful not only for academics and examinations but also for personal fortification. 


\subsection{Using Technology to Improve Writing Skills}

Writing is an integral part of education. Besides having a command on reading skills, writing adeptness is essential for academic success (Graham \& Perin, 2007). Writing enables development of advanced level thinking ability, is one of the important talents assessed during employment and promotion and is a fundamental prerequisite to successfully participate in social life and in an international economy (National Writing Project \& Nagin, 2006; National Commission on Writing, 2003; National Commission on Writing, 2004). Students with LD exhibit a remarkable range of writing problems (Harris, Graham \& Mason, 2006). Often, they lack writing talent as per the requirements of regular class. They have to work on their isolated capabilities and fail to get a wider picture of the actual educational environment (Graham, Harris, Fink-Chozempa \& MacArthur, 2003). They face problems in planning and organizing, editing, revising, transcribing words and creating topics (Patel \& Laud, 2007; Troia, 2006). As per a study by Newcomer \& Barenbaum (1991), students with LDs commit more mechanical mistakes like punctuation, capitalization and spelling, with the last one being the most common, are likely to make errors in syntax, have less fluency and have few chances of improving their fluency with age. Thus, in comparison to their normal peers, students with LD have lesser skills that usually do not improve with time or age. The results of the NAEP (National Assessment of Educational Progress) (2007) found that almost $45 \%$ of students with LD do not even have the minimum proficiency level in writing, thereby indicating their poor standard of writing ability ( NAEP, 2007). Students with LD exhibit writing ability almost six times below the minimum level as compared to their normal peers. For writing to improve for students with LD, their writing lessons also need to be improved (Graham \& Perin, 2007; National Commission on Writing, 2006). In spite of teachers knowing about how to improve writing skills of students with LD, effective approaches like making correct use of technology are not commonly used. The National Commission on Writing (2003) has recommended application of prevailing writing technologies and providing professional and technical training to all teachers to assist in improving the writing skills of students with LD. Technology has the capability to support both writing and teaching writing skills (National Commission on Writing, 2003).

Technology can provide new options for writing namely technology-assisted writing, technology-enabled writing and multimedia writing (National Council of Teachers of English, 2004). Technology-assisted writing can help in all stages of writing like planning, transcribing, editing, revision. Apart from word processors, spell checkers, text-to-speech, organizers and word prediction tools have the potential to assist students with LD to make use of different cognitive levels required to create an organized, reader-friendly, rational and typically correct composition (Hunt-Berg \& Rankin, 1994; Forgrave, 2002; MacArthur, 2000, 2009a, 2009b; Montgomery \& Marks, 2006; Sitko,Laine \& Sitko, 2005; Zhao, 2007). Technology-enabled writing offers new sources for retrieving information like Internet and search engines. It enables real-time sharing, editing and association of students having LD with their peers and teachers.

Technology helps in improving writing skills by providing new multimedia forms and electronic genres. These are composed of a mixture of media like still pictures, video, sound 
and print (National Council of Teachers of English, 2004). Digital writing helps to create, express and communicate in unexplored manners for students with LD as compared to a pen-and-pencil approach (National Writing Project \& DeVoss, Eidman-Aadahl \& Hicks, 2010). Tools available for composing are not just limited to the word processor. The list includes various digital technologies for recording (encoding) information like voice recorders, digital cameras and scanners. However, the use of technologies like word processor for assessing writing skills is neither commonly used among educational institutes nor has been established as the norm amongst various states (Russell \& Abrams, 2004; Russell, Goldberg \& O'Connor, 2003). The old writing forms continue to be used in education. For students with LD to become proficient in writing, critical assessment of the various tools and technologies that can help in providing compensatory advantage and overcome barriers resulting from their physical and cognitive aspects is required on an immediate basis (Peterson-Karlan \& Parette, 2008). The success of transcription tools, editing and revising tools in improving the writing skills of students with LD has been proved by Peterson-Karlon (2011).

Digital storytelling can help in improving proficiency of students with their basic knowledge level as it uses a mixture of visuals, sound and narration via technology. Once the students become adept at drafting, correcting and editing written stories, the final product is digital media creation like a Movie Maker, PhotoStory or iMovie. This can help the students discover their hidden talent in writing with the help of technologies they are used to (Kadjer, 2006). Students with LD, by using visual tools, find new means to express language and to represent their thinking's in words (Rose \& Meyer, 2002). Such use of technology helps to transform their writing experiences into fun learning exercise and also helps in confirming to the state requirements for integrating technology into the course syllabus (Routman, 2004). Expressive writing programs can also help in improving the writing skills of students with LDs (Walker, Shippen, Houchins \& Cihak, 2007). Thus, various forms of technology can be effectively used to improve the writing skills of students with LD.

\subsection{Using Technology to Improve Math}

Effectively integrating technology within regular math classes enables students to gain and understand new information. Assistive technology for math helps students with LD to compute, organize, align and copy math problems on paper. Students are able to set up and compute basic mathematical problems using audio and/or visual aid. Allsopp, Farmer and McHatton (2010) have categorized technologies related to useful math teaching for students with LD into two ways. One is the kind of technology that helps to circumvent a disability hurdle like calculator. Second is technology that improves instructional techniques and assists teachers in making positive instructional decisions like interactive white boards. $\mathrm{Li}$ and $\mathrm{Ma}$ (2010) found that technological interventions when used for a short period of six or less months is more effective in enhancing mathematical skills as compared to longer duration of intervention of six to twelve months. It also showcased that technology could actually help students with LD in math. Technology can offer useful learning prospects for improving advanced level thinking and problem-solving abilities required to work efficiently in the real world for students with LD. Software like FASTT (Fluency and Automaticity through 
Systematic Teaching) helps students with strategy-based procedural counting, which includes algorithms, rules or techniques to resolve mathematical problems like the order of operations. O’Malley, Jenkins, Wesley, Donehower, Rabuck and Lewis (2013) assessed the effectiveness of using fundamental math skill applications on an iPad to enhance fundamental math fluency of students with LD. This study found that iPad was an effective and useful tool for students suffering from medium to severe LD. Technology helped to improve the average number of correct problems solved by these students per minute with the help of iPad application Math Racer. The benefits resulting from the use of iPad application included it being extremely acceptable and effectual for teachers to provide instructions in class, enabled students to gain expertise towards learning objectives not yet attempted, improved the teaching skills as well as helped in improving interest of students in the subject. Thus, research has proved that students with LD can learn math and be successful if empowered with the right technology.

Besides technology being effective to improve reading, writing and math skill of students with LD, it is equally effective in improving their listening skill. Belson, Hartmann and Sherman (2013) discovered that those students with LD using commercially available digital pens for taking down notes improved the standard of their notes due to aspects like audio feedback that enabled students to overcome their problems in concentrating to details. Their concentration during lectures also increased as a result of reduced anxiety related to taking notes. Thus, technology can help students with LD overcome their weaknesses in various segments. However, continuous research is required to review the technology suitable for students with LD.

\subsection{Recommendations for Future Practice and Research}

Teachers should effectively implement technology in their classes by allotting time to apply their knowledge gained from teaching experience into creating suitable technology by collaborating with parents and assistive technologists. They should be regularly trained, be able to connect technology to educational aims and sustain their knowledge and progress through regular training (Brand, 1997). Using technology will enable teachers to modify their teaching practices towards inclusive pedagogy (Windschitl \& Sahl, 2002). All efforts should be made to create an inclusive learning environment for students with LD with the help of technology.

More number of high-level researches on use of latest technologies to assist education of students with LD is required to be conducted on an immediate basis. The effectiveness of latest technologies in helping them overcome their weaknesses and the manner in which technology can actually help in improving the skills they lack needs more stringent measurement scale. These advanced researches will enable systematic expansion of knowledge of educationists dealing with students having LD and help to decide the best technology-aided instructional procedures for such students who constantly fight to overcome their weaknesses in this highly advanced digital era.

Thus, effective implementation of technology in public education for helping students with LD requires a comprehensive plan that incorporates technology in such a manner that assists learning of the regular curriculum, ensures required resources for timely implementation of 
the plan and fosters professional growth and an optimistic outlook among the teaching staff (Hew \& Brush, 2007). During deciding the assistive technology to be used, conventional, commercially available and customized technologies should be taken into consideration to meet the students' requirements and to decide if technology will have a stigmatizing impact (Bouck, Flanagan, Miller \& Bassette, 2012).

\section{Conclusion.}

The objective of this research study was to understand the existing knowledge regarding effectiveness of technology to promote academic success of students with LD by referring to relevant authoritative sources and to determine whether using technology to support education of students with LD is an evidence-based practice. Good learning practices should focus on the requirements of learners and should result in continual progress of students with LD in spite of their limited learning capabilities. Schools and educationists need to execute requisite pedagogy in such a manner that students with LD are benefitted rather than confining them to special instructions and objectives. Integrating technology into regular education to support students with LD need not be costly or necessitate massive training. Assistive technology ranging from low-tech devices like pencil grips to advanced software like speech recognition software can empower children having LD with the skills required to take forward their education in an equivalent manner like their peers. Emerging technologies like social networking sites and freely available communication software can aid effective association with teachers and peers. Continuous policy up gradation and research can immensely contribute towards technology incorporation within teaching lessons for students with different academic LD. In all instances of integrating assistive technology, the solution is to choose the right technological tool as per the strengths and requirements of students with LD and to train students, parents and teachers regarding usage of technology in the most consistent and effective manner.

\section{References}

Allsopp, D. H., Farmer, J. L., \& McHatton P. A. (2010). Technology, mathematics PS/RTI, and students with LD: What do we know, what have we tried, and what can we do to improve outcomes now and in the future? Learning Disability Quarterly, 33(4), 273. http://dx.doi.org/10.1177/073194871003300405

American Academy of Child, \& Adolescent Psychiatry. (2015). Children with learning disorders. $\quad$ Retrieved from https://www.aacap.org/AACAP/Families_and_Youth/Facts_for_Families/Facts_for_Families _Pages/Children_With_Learning_Disabilities_16.aspx.

Anderson-Inman, L., Ditson, L., \& Ditson, M.T. (1998). Computer-based concept mapping: Promoting meaningful learning in science for students with disabilities. Information Technology and Disabilities Journal, 1-2. Retrieved from http://itd.athenpro.org/volume5/number1-2/article2.html.

Bahr, C. M., Nelson, N. W., \& VanMeter, A. M. (1996). The effects of text-based and graphics-based software tools on planning and organizing of stories. Journal of Learning 
Disabilities, 29, 355-370. http://dx.doi.org/10.1177/002221949602900404

Belson, S. I., Hartmann, D., \& Sherman, J. (2013). Digital note taking: The use of electronic pens with students with specific learning disabilities. Journal of Special Education Technology, 28(2), 13-24. http://dx.doi.org/10.1177/016264341302800202

Berry, R. A. W. (2006). Creating a better classroom environment for students with learning disabilities. Learning Disability Quarterly, 32(3), 123-141.

Boote, D.N., \& Beile, P. (2005). Scholars before researchers: On the centrality of the dissertation literature review in research preparation. Educational Researcher, 34(6), 3-15. http://dx.doi.org/10.3102/0013189X034006003

Bouck, E. C., Flanagan, S., Miller, B., \& Bassette, L. (2012). Technology in action: Rethinking everyday technology to meet students' IEP goals. Journal of Special Education Technology, 27(4), 47-47. http://dx.doi.org/10.1177/016264341202700404

Brand, G. A. (1997). What research says: Training teachers for using technology? Journal of Staff Development, 19(1), 1-9.

Braun, V., \& Clark, V. (2006). Using thematic analysis in psychology. Qualitative Research in Psychology, 3, 77-101. http://dx.doi.org/10.1191/1478088706qp063oa

Bryant, D. P., \& Bryant, B. R. (1998). Using assistive technology adaptations to include students with learning disabilities in cooperative learning activities. Journal of Learning Disabilities, 31, 41-54. http://dx.doi.org/10.1177/002221949803100105

Calhoon, M. B., Sandow, A. \& Hunter, C. V. (2010). Reorganizing the instructional reading components: Could there be a better way to design remedial reading programs to maximize middle school students with reading disabilities' response to treatment? Annals of Dyslexia, 60(1), 57-85. http://dx.doi.org/10.1007/s11881-009-0033-x

Carpenter, D. R. (2011). Ethical Considerations in Qualitative Research. In H.S.Speziale, H.J. Streubert and D.R.Carpenter (eds.), Qualitative research in nursing: advancing the humanistic principle (pp. 56-69). Philadelphia: Lippincott, Williams \& Wilkins.

CASP. (2013). CASP Checklists. Retrieved from http://media.wix.com/ugd/dded87_951541699e9edc71ce66c9bac4734c69.pdf.

Chard, D. J., Vaughn, S. \& Tyler, B. J. (2002). A synthesis of research on effective interventions for building reading fluency with elementary students with learning disabilities. Journal of Learning Disabilities, 356-406. http://dx.doi.org/10.1177/00222194020350050101

Cook, L., \& Friend, M. (1996). The fundamentals of collaboration. In L. W. Witzling (ed.), Interactions: Collaboration skills for school professionals (pp. 1- 20). New York: Longman.

Denzin, N., \& Lincoln, Y. (2000). Handbook of qualitative research (2nd ed.). London: Sage Publications. 
Ely, C., \& Scott, I. (2007). Essential study skills for nursing. Edinburgh: Elsevier.

Fletcher, J. M., Stuebing, K. K., Barth, A. E., Denton, C. A., Cirino, P. T., Francis, D. J. \& Vaughn, S. (2011). Cognitive correlates of inadequate response to reading intervention. School Psychology Review, 40(1), 3-22.

Forgrave, K. E. (2002). Assistive technology: empowering students with learning disabilities. Clearing House, 75, 122-126. http://dx.doi.org/10.1080/00098650209599250

Fuchs, L. \& Fuchs, D. (2009). Creating opportunities for intensive intervention for students with learning disabilities. Teaching Exceptional Children, 42(2), 60-62. http://dx.doi.org/10.1177/004005990904200207

Graham, S., \& Perin, D. (2007). A metaanalysis of writing instruction for adolescent students. $\begin{array}{lllll}\text { Journal of } & \text { Educational } & \text { Psychology, } & 99, & \text { 99 }\end{array}$ http://dx.doi.org/10.1037/0022-0663.99.3.445

Graham, S., Harris, K., Fink-Chorzempa, B., \& MacArthur, B. (2003). Primary grade teachers' instructional adaptations for struggling writers: A national survey. Journal of Educational Psychology, 95(2), 279-292. http://dx.doi.org/10.1037/0022-0663.95.2.279

Haager, D., Klinger, J., \& Vaughn, S. (2007). Evidence based reading practices for response to intervention. Baltimore, MD: Paul H. Brookes Publishing.

Harris, K., Graham, S., \& Mason, L. (2006). Improving the writing, knowledge, and motivation of struggling young writers: Effects of self-regulated strategy development with and without peer support. American Educational Research Journal, 43(2), 295-340. http://dx.doi.org/10.3102/00028312043002295

Hartry, A., Fitzgerald, R. \& Porter, K. (2008). Implementing a structured reading program in an afterschool setting: Problems and potential solutions. Harvard Educational Review, 78(1), 181-210. http://dx.doi.org/10.17763/haer.78.1.b12374m521j08812

Hew, K. F., \& Brush, T. (2007). Integrating technology into K-12 teaching and learning: Current knowledge gaps and recommendations for future research. Education Technology Research Development, 55, 223-252. http://dx.doi.org/10.1007/s11423-006-9022-5

Hewes, G. M., Palmer, N., Haslam, M. B., \& Mielke, M. B. (2006). Five years of Read 180 in Des Moines: Improving literacy among middle school and high school special education students. Washington, D.C.: Policy Study Associates.

Hunt-Berg, M., \& Rankin, J. L. (1994). Ponder the possibilities: Computer-supported writing for struggling writers. Learning Disabilities Research and Practice, 9, 169-178.

Individuals with Disabilities Education Act Amendments (1997). Retrieved from http://www2.ed.gov/offices/OSERS/Policy/IDEA/index.html.

Jacobs, P., \& Fu, D. (2014). Students with learning disabilities in an inclusive writing classroom. Journal of Language and Literacy Education, 10(1), 100-113. 
Joffe, H. \& Yardley, L. (2004). Content and Thematic Analysis. In: Research Methods for Clinical and Health Psychology (pp. 56-68.). London: Sage.

Kadjer, S. (2006). Bringing the outside in. Visual ways to engage reluctant readers. Portland, ME: Stenhouse Publishers.

LDA (Learning Disabilities Association of America). (2015). Types of learning disabilities. Retrieved from http://ldaamerica.org/types-of-learning-disabilities/.

Lee, P. (2006). Qualitative research. Nursing Times, 102(29), 0-32.

Lewis, L. B. (1998). Assistive technology and learning disabilities: Today's realities and tomorrow's promises. Journal of Learning Disabilities, 31, 16-26. http://dx.doi.org/10.1177/002221949803100103

Li, Q., \& Ma, X. (2010). Technology on school students' mathematics learning. Educational Psychology Review, 22(3), 15. http://dx.doi.org/10.1007/s10648-010-9125-8

MacArthur, C. A. (1996). Using technology to enhance the writing processes of students with learning disabilities. Journal of Learning Disabilities, 29, 344-354. http://dx.doi.org/10.1177/002221949602900403

MacArthur, C. A. (2000). New tools for writing: Assistive technology for students with writing difficulties. Topics in Language Disorders, 20(4), 85-100. http://dx.doi.org/10.1097/00011363-200020040-00008

MacArthur, C. A. (2009a). Reflections on research on writing and technology for struggling writers. Learning Disabilities Research and Practice, 24, 93-103. http://dx.doi.org/10.1111/j.1540-5826.2009.00283.x

MacArthur, C. A. (2009b). Using technology to teach composing to struggling writers. In G. A. Troia (ed.), Instruction and assessment for struggling writers (pp. 243-265). New York: Guilford.

MacArthur, C. A., \& Graham, S. (1987). Learning disabled students' composing under three methods of text production: Handwriting, word processing, and dictation. Journal of Special Education, 21, 22-42. http://dx.doi.org/10.1177/002246698702100304

MacArthur, C. A., Graham, S., \& Schwartz, S. S. (1991). A model for writing instruction: Integrating word processing and strategy instruction into a process approach to writing. Learning Disabilities Research \& Practice, 6, 230-236.

McPhail, J. C. \& Freeman, J. G. (2005). Beyond prejudice: Thinking towards genuine inclusion. Learning Disabilities Research \& Practice, 20(4), 254-267. http://dx.doi.org/10.1111/j.1540-5826.2005.00141.x

Moule, P. \& Goodman, M., (2014). Nursing Research: An Introduction (2nd ed.). London: Sage Publication Ltd.

NAEP. (2007). The nation's report card: Writing 2007. Retrieved from http://nces.ed.gov/nationsreportcard/pdf/main2007/2008468.pdf. 
National Commission on Writing. (2003). The Neglected R: The need for a writing revolution. Retrieved from http://www.nwp.org/cs/public/print/resource/2523.

National Commission on Writing. (2004). Writing: A ticket to work...Or a ticket out. Retrieved from http://www.nwp.org/cs/public/print/resource/2540.

National Commission on Writing. (2006). Writing and school reform. Retrieved from http://www.nwp.org/cs/public/print/resource/2542.

National Council of Teachers of English. (2004). NCTE beliefs about the teaching of writing. Retrieved from http://www.ncte.org/positions/statements/writingbeliefs.

National Writing Project \& DeVoss, D. N., Eidman-Aadahl, E., \& Hicks, T. (2010). Because digital writing matters: Improving students writing online and in multimedia environments. San Francisco: Jossey-Bass.

National Writing Project, \& Nagin, C. (2006). Because writing matters: Improving student writing in our schools. San Francisco: JosseyBass.

Newcomer, P. L., \& Barenbaum, E. M. (1991). The written composing ability of children with learning disabilities: A review of the literature from 1980 to 1990. Journal of learning Disabilities, 24, 578-593. http://dx.doi.org/10.1177/002221949102401001

NIH. (2014). What are the indicators of learning disabilities. Retrieved from https://www.nichd.nih.gov/health/topics/learning/conditioninfo/pages/symptoms.aspx.

Office of Special Education Programs. (2011). Retrieved from http://www2.ed.gov/fund/grant/apply/osep/index.html.

O’Malley, P., Jenkins, S., Wesley, B., Donehower, C., Rabuck, D., \& Lewis, M. E. B. (2013). Effectiveness of using ipads to build math fluency. Retrieved from http://files.eric.ed.gov/fulltext/ED541158.pdf.

Onwuegbuzie, A.J., Leech, N.L., \& Collins, K.M.T. (2010) Innovative data collection strategies in qualitative research. The Qualitative Report, 15(3), 696-726.

Patel, P., \& Laud, L. (2007). Integrating a story writing strategy into a resource curriculum. Teaching Exceptional Children, 34-41. http://dx.doi.org/10.1177/004005990703900404

Peterson-Karlan, G.R. (2011). Technology to support writing by students with learning and academic disabilities. Assistive Technology Outcomes and Benefits, 7(1), 39-62.

Peterson-Karlan, G. R., \& Parette, H. P. (2008). Integrating assistive technology into the curriculum. In H. P. Parette \& G. R. Peterson-Karlan (eds.), Research-based and emerging best practices in developmental disabilities (pp. 183-214). Austin: ProEd.

Pitcher, S. M., Martinez, G., Dicembre, E. A., Fewster, D. \& McCormick, M. K. (2010). The literacy needs of adolescents in their own words. Journal of Adolescents and Adult Literacy, 53(8), 636-645. http://dx.doi.org/10.1598/JAAL.53.8.2 
Polit, D. \& Beck, C. (2010). Essentials of Nursing Research: Methods, Appraisal and Utilization (7th ed.). Philadelphia, PA: Lippincott Williams and Wilkins.

Pooler, D. (2012). An Introduction to Evidence-based Practice in Nursing and Healthcare. London: Pearson Education Ltd.

Quenneville, J. (2015) Tech tools for students with learning disabilities: Infusion into inclusive classrooms. Retrieved from http://www.ldonline.org/article/6380/.

Reed, P., Clifford, M. \& Svedkauskaite, A. (2004). Critical issue: Enhancing system change and academic success through assistive technologies for $\mathrm{K}-12$ students with special needs. Retrieved from http://www.ncrel.org/sdrs/areas/issues/methods/technlgy/te700.htm.

Rose, D., \& Meyer, A. (2002). Teaching every student in the digital age. Universal design for learning. Alexandria, VA: ASCD.

Routman, R. (2004). Writing essentials: Raising expectations and results while simplifying teaching. Portsmouth, NH: Heinemann.

Russell, M., \& Abrams, L. (2004). Instructional uses of computers for writing: The effect of state testing programs. Teachers College Record, 106, 1332-1357. http://dx.doi.org/10.1111/j.1467-9620.2004.00381.x

Russell, M., Goldberg, A., \& O'Connor, K. (2003). Computer-based testing and validity: A look back into the future. Assessment in Education: Principles, Policy \& Practice, 10, 279-293. http://dx.doi.org/10.1080/0969594032000148145

Scholastic Inc. (2011). Read 180 reading intervention program: A comprehensive reading intervention solution. Retrieved from http://www.scholastic.com/read180/.

Schumaker, J. B., Deshler, D. D., Woodruff, S. K., Hock, M. F., Bulgren, J. A., \& Lenz, B. K. (2006). Reading strategy interventions: Can literacy outcomes be enhanced for at-risk adolescents? Teaching Exceptional Children, 38(3), 64-68. http://dx.doi.org/10.1177/004005990603800310

Shores, C., \& Bender, W. H. (2007). Response to intervention: A practical guide for every teacher. Thousand Oaks, CA: Corwin Press.

Sitko, M. C., Laine, C. J., \& Sitko, C. J. (2005). Writing tools: Technology \& strategies for struggling writers. In D. L. Edyburn, K. Higgins, \& R. Boone (eds.), Handbook of special education research and practice (pp. 571- 598). Whitefish Bay, WI: Knowledge by Design.

Slavin, R. E., Cheung, A. Groff, C., \& Lake, C. (2008). Effective reading programs for middle and high schools: A best-evidence synthesis. Reading Research Quarterly, 43(3), 290-322. http://dx.doi.org/10.1598/RRQ.43.3.4

Stetter, M. E. \& Hughes, M. T. (2010). Computer assisted instruction to enhance the reading comprehension of struggling readers: A review of the literature. Journal of Special Education, 25(4), 1-12. http://dx.doi.org/10.1177/016264341002500401

Tenny, J. (1992). Computer-supported study strategies for purple people. Reading and writing 
quarterly: Overcoming learning difficulties, $\quad 8, \quad 359-377$. http://dx.doi.org/10.1080/0748763920080404

Troia, G. A. (2006). Writing instruction for students with learning disabilities. In C. A. MacArthur, S. Graham \& J. Fitzgerald (eds.), Handbook of writing research (pp. 324- 336). New York, NY: Guilford Press.

US Department of Education. (2010). Transforming American education: Learning powered by technology. Retrieved from https://www.ed.gov/sites/default/files/netp2010.pdf.

US Department of Education. (2014). Office of Special Education Programs 2011. Retrieved from http://www2.ed.gov/policy/landing.jhtml?src=pn.

Vacc, N. N. (1987). Word processor versus handwriting: A comparative study of writing samples produced by mildly mentally handicapped students. Exceptional Children, 54, 156-165.

Van Kraayenoord, K. E., Miller, R., Moni, K., \& Jobling, A. (2009). Teaching writing to students with learning disabilities in inclusive English classrooms: Lessons from an exemplary teacher. English Teaching: Practice and Critique, 8(1), 23-51.

Walker, B. D., Shippen, M. E., Houchins, D. E., \& Cihak, D. F. (2007). Improving the writing skills of high school students with learning disabilities using the "Expressive Writing" Program. International Journal of Special Education, 22(2), 66-76.

Webster, J., \& Watson, R. T. (2002) Analyzing the past to prepare for the future: Writing a literature review. MIS Quarterly, 26(2), 48-49.

White, R. N., Haslam, M. B. \& Hewes, G. M. (2006). Improving student literacy: Read 180 in the Phoenix Union High School District, 2003-04 and 2004-05. Washington, D.C.: Policy Studies Associates.

Wilson, C. H., Brice, C., Carter, E.I. Fleming, J. C, Hay, D.D., Hicks, J. D., Picot, E., Taylor, A.M., \& Weaver, J.(2011). Familiar technology promotes academic success for students with exceptional learning needs. Retrieved from http://files.eric.ed.gov/fulltext/ED530541.pdf.

Windschitl, M. \& Sahl, K. (2002). Tracing teachers' use of technology in a laptop computer school: The interplay of teacher beliefs, social dynamics, and institutional culture. American Educational Research Journal, 39(1), 165-205. http://dx.doi.org/10.3102/00028312039001165

\section{Copyright Disclaimer}

Copyright for this article is retained by the author(s), with first publication rights granted to the journal.

This is an open-access article distributed under the terms and conditions of the Creative Commons Attribution license (http://creativecommons.org/licenses/by/3.0/). 